\title{
Regulation of Parathyroid Hormone Gene Expression by Hypocalcemia, Hypercalcemia, and Vitamin D in the Rat
}

Tally Naveh-Many and Justin Silver

Mineral Metabolism Unit, Nephrology and Hypertension Services, Hadassah University Hospital, Jerusalem, Israel

\begin{abstract}
In vivo in the rat $1,25(\mathrm{OH})_{2} \mathrm{D}_{3}$ decreases and a low calcium increases PTH mRNA levels. We now report the effect of 3 and 8 wk of changes in dietary vitamin D and calcium on PTH mRNA levels. PTH mRNA levels were increased by 3 wk of calcium deficiency (five times), a vitamin D-deficient diet (two times), and combined deficiency (10 times), but not changed by high calcium. Vitamin D-deficient-diet rats' PTH mRNA did not decrease after a single large dose of $1,25(\mathrm{OH})_{2} \mathrm{D}_{3}$, but did decrease partially after repeated daily doses of $1,25(\mathrm{OH})_{2} \mathrm{D}_{3}$. Rats after a vitamin D-, calcium-deficient (-D-Ca) diet did not respond to changes in serum calcium at $1 \mathrm{~h}$. Flow cytometry of isolated cells from parathyroid-thyroid tissue separated the smaller parathyroid from the larger thyroid cells and allowed an analysis of parathyroid cell number. In normal vitamin D/normal calcium (NDNCa) rats the parathyroid cells were $24.7 \pm 3.4 \%(n=6)$ of the total cell number, whereas in $-D-C a$ rats they were $41.8 \pm 6.6 \%(n=6)(P<0.05)$. That is, -D-Ca rats had 1.7 times the number of cells, whereas they had 10 times the amount of PTH mRNA, indicating the major contribution (6 times) of increased PTH gene expression per cell. Moreover, a calcium-deficient, more so than a vitamin D-deficient diet, amplifies the expression of the PTH gene, and vitamin $D$ is necessary for an intact response of PTH mRNA to $1,25(\mathrm{OH})_{2} D_{3}$ or calcium. (J. Clin. Invest. 1990. 86:13131319.) Key words: parathyroid hormone $\mathrm{mRNA} \cdot 1,25(\mathrm{OH})_{2} \bullet$ vitamin $\mathrm{D} \cdot$ flow cytometry $\bullet$ gene regulation $\bullet$ calcium
\end{abstract}

\section{Introduction}

The hormones PTH, 1,25-dihydroxyvitamin $\mathrm{D}_{3}\left(1,25(\mathrm{OH})_{2} \mathrm{D}_{3}\right)^{1}$ and calcitonin are the major calciotrophic hormones. Calcium not only determines PTH secretion but also regulates PTH gene expression both in vitro $(1,2)$ and in vivo $(3,4)$. Calcitonin, on the other hand, is secreted in response to a high calcium but its transcription is not affected by calcium (4). The transcription of both PTH and calcitonin genes is markedly reduced by $1,25(\mathrm{OH})_{2} \mathrm{D}_{3}$ both in vitro $(5-7)$ and in vivo $(8,9)$, suggesting a

Address reprint requests to Dr. J. Silver, Mineral Metabolism Unit, Nephrology and Hypertension Services, Hadassah University Hospital, POB 12000, Jerusalem, Israel 91120.

Received for publication 2 February 1990 and in revised form 29 May 1990

1. Abbreviations used in this paper: FDA, fluorescein diacetate; $1,25(\mathrm{OH})_{2} \mathrm{D}_{3}, 1,25$-dihydroxyvitamin $\mathrm{D}_{3}$.

J. Clin. Invest.

(c) The American Society for Clinical Investigation, Inc. $0021-9738 / 90 / 10 / 1313 / 07 \$ 2.00$

Volume 86, October 1990, 1313-1319 central role for $1,25(\mathrm{OH})_{2} \mathrm{D}_{3}$ in orchestrating calcium homeostasis.

The regulation of PTH gene transcription is relevant not only in understanding the physiology of the parathyroid gland, but also in the pathophysiology of diseases involving the parathyroid where there is parathyroid hyperplasia. Secondary parathyroid hyperplasia is a complication of chronic renal disease or vitamin D deficiency, and may lead to disabling skeletal complications. We have therefore studied the regulation of PTH gene expression in parathyroid hyperplasia in rats due to dietary deficiencies of calcium and/or vitamin $\mathrm{D}$, as well as the effect of a high dietary calcium causing chronic hypercalcemia. We have demonstrated in vivo in the rat that PTH mRNA levels are not affected by a high calcium, but are increased by a vitamin D-deficient diet and even more so by a calcium deficient diet. Vitamin D-deficient rats did not respond normally to single doses of $1,25(\mathrm{OH})_{2} \mathrm{D}_{3}$ or acute changes in serum calcium.

The relative contribution of increased transcription per parathyroid cell to increased cell number was studied.

\section{Methods}

Animals. Weanling male Hebrew University strain rats $(30 \mathrm{~g})$ were maintained in an UV light-free environment for 3 or $8 \mathrm{wk}$ on the following diets (Teklad, IL): normal vitamin D, $0.4 \%$ calcium (NDNCa) (TD 88304); normal vitamin D, $0.02 \%$ calcium (ND-Ca) (TD 88346); normal vitamin D, $2 \%$ calcium (ND+Ca) (TD 88305); vitamin D deficient, $0.4 \%$ calcium ( - DNCa) (TD 85049); vitamin D deficient, $0.02 \%$ calcium ( $-\mathrm{D}-\mathrm{Ca}$ ) (TD 85048); vitamin D deficient, $2 \%$ calcium $(-\mathrm{D}+\mathrm{Ca})$ (TD 89155$)$. Some rats were then treated intraperitoneally with $1,25(\mathrm{OH})_{2} \mathrm{D}_{3}$, calcium gluconate, or calcitonin (4). The thyroids with attached parathyroids were excised under pentobarbital anesthesia and blood samples were taken. The excised tissue was immediately frozen in liquid nitrogen and stored at $-70^{\circ} \mathrm{C}$ until extraction. There were four rats in all groups studied but there were only three rats in the groups fed vitamin D-deficient diets $(-D)$ for $8 \mathrm{wk}$, because one rat died $(-D+C a)$, and serum was pooled from 2 rats of $-\mathrm{D}-\mathrm{Ca}$ and $-\mathrm{DNCa}$.

Measurement of cellular mRNA levels. Total RNA was prepared from thyroid-parathyroid by homogenization in guanidium thiocyanate as previously described (8). Dot blots of total tissue RNA extracts were prepared by formaldehyde denaturation followed by serial dilutions with $15 \times$ SSC. The diluted samples were spotted on a nitrocellulose filter $(0.45 \mu \mathrm{m}$; Schleicher \& Schuell, Keene, NH) soaked in $10 \times$ SSC, using a manifold apparatus. For Northern blots, RNA and markers were denatured and size-fractionated by electrophoresis on $1.5 \%$ agarose gels containing formaldehyde and transferred to nitrocellulose filters by diffusion blotting. The filters were baked at $80^{\circ} \mathrm{C}$ for $120 \mathrm{~min}$ in a vacuum oven. Dot blots and Northern blots were hybridized to rat preproPTHcDNA in plasmid PT43, using a nick-translated gel-purified restriction fragment $\left(2-5 \times 10^{8} \mathrm{cpm} / \mu \mathrm{g}\right)$ as before (8).

Serum calcium was measured in a Roche autoanalyzer. Serum $1,25(\mathrm{OH})_{2} \mathrm{D}_{3}$ levels were measured by a radioreceptor assay after chromatography on HPLC. 
Flow cytometry of thyroparathyroid cells (10). For sample preparation, thyroparathyroid tissue from normal rats (NDNCa) and $-\mathrm{D}-\mathrm{Ca}$ rats was placed in $\mathrm{BME}$ medium with $5 \% \mathrm{FCS}$ at $4^{\circ} \mathrm{C}$, minced and then incubated with collagenase $(500 \mathrm{U} / \mathrm{ml})$ (Worthington Biomedicals, Malvern, PA) at $37^{\circ} \mathrm{C}$ for $1 \mathrm{~h}$ in a shaking water bath. There was complete digestion of the glands to isolated cells. The cell suspension was filtered through a nylon mesh, then centrifuged at $400 \mathrm{~g}$ for $5 \mathrm{~min}$ at $4^{\circ} \mathrm{C}$, washed twice in Hanks buffer and the pellet resuspended in 500 $\mu \mathrm{l}$ of Hanks' buffer.

Fluorescent staining with 3',6'-diacetyl fluorescein (FDA) and propidium iodide. Diacetyl fluorescein (Sigma Chemical Co., St. Louis, MO) dissolved in acetone $(5 \mathrm{mg} / \mathrm{ml})$ was stored at $-20^{\circ} \mathrm{C}$. Immediately before analysis $1 \mu \mathrm{l}$ FDA was added to $100 \mu \mathrm{l}$ of parathyroid-thyroid cell suspension $(11,12)$. To other dilute cell suspensions propidium iodide $(50 \mu \mathrm{g} / \mathrm{ml})$ was added at $1 \mu \mathrm{l}$ to $100 \mu \mathrm{l}$ of cell suspension (10).

Measurement procedure. The samples were analyzed by a FACS 440 cell sorter (Becton-Dickinson Co., Malvern, PA) using $300 \mathrm{mV}$ excitation at $488 \mathrm{~nm}$ from an argon ion laser source. The diameter of the nozzle used was $70 \mu \mathrm{m}$. The fluorescent angle light scatter was at $520 \mathrm{~nm}(11)$

Statistics were analyzed by $t$ test.

\section{Results}

After $3 \mathrm{wk}$ of the diets serum $1,25(\mathrm{OH})_{2} \mathrm{D}_{3}$ levels were not significantly different: for control rats (NDNCa), the levels were $154 \pm 20 \mathrm{pg} / \mathrm{ml}(n=3)$, for ND+Ca rats, the levels were $167 \pm 6 \mathrm{pg} / \mathrm{ml}(n=3)$, and for -DNCa rats, the levels were $124 \pm 12 \mathrm{pg} / \mathrm{ml}(n=4)$. However, ND-Ca rats had higher levels: $858 \pm 61 \mathrm{pg} / \mathrm{ml}(n=3), P<0.01$, compared to NDNCa, and $-\mathrm{D}-\mathrm{Ca}$ rats had lower levels: $90.7 \pm 13 \mathrm{pg} / \mathrm{ml}(n=3), P$ $<0.05$ compared with NDNCa

After $3 \mathrm{wk}$ of the diets given to weanling rats, serum calcium and PTH mRNA were strikingly different amongst the groups (Fig. 1), whereas actin mRNA levels were the same in all the groups (not shown). The control group (NDNCa) had a mean serum calcium of $10.6 \mathrm{mg} / \mathrm{dl}$, which increased to 12.2 $\mathrm{mg} / \mathrm{dl}$ on a calcium-enriched diet (ND+Ca) but had no effect on PTH mRNA. Rats after a vitamin D-deficient diet with a

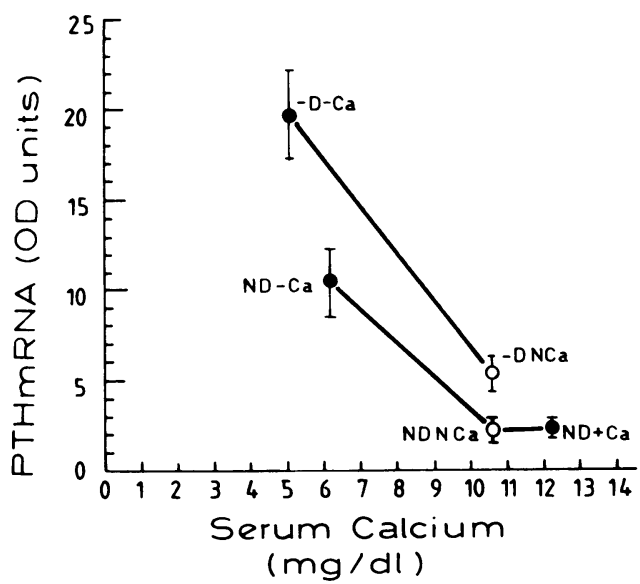

Figure 1. Effect of dietary calcium and vitamin D on serum calcium and PTH mRNA levels of rat parathyroid glands. Results as mean \pm SEM for four rats are shown for rats on control diet $(N D N C a)$; high calcium $(N D+C a)$; vitamin D-deficient normal calcium $(-D N C a)$; normal vitamin $\mathrm{D}$, calcium-deficient $(N D-C a)$; vitamin D-, calcium-deficient $(-D-C a)$.

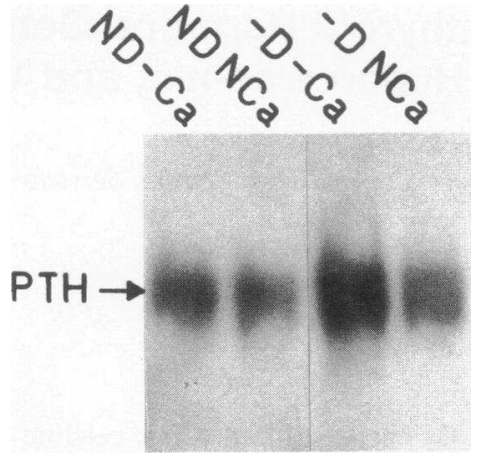

Figure 2. Gel blot analysis of total RNA from parathyroid-thyroid tissue from rats on different diets after hybridization with ${ }^{32} \mathrm{P}$ nick-translated PTH cDNA. Lanes: $\mathrm{ND}-\mathrm{Ca}$ normal vitamin $D$, calcium-deficient; $-D-C a$, vitamin D- and calcium-deficient; $-D N C a$, vitamin Ddeficient, normal calcium.

normal dietary calcium content ( $-\mathrm{DNCa}$ ) had serum calciums of $10.6 \mathrm{mg} / \mathrm{dl}$, with a twofold increase in their PTH mRNA levels. Calcium-deficient rats who were vitamin $D$ replete (ND-Ca) had a low serum calcium $(6.3 \mathrm{mg} / \mathrm{dl})$ and a fivefold increase in PTH mRNA, whereas after a vitamin D- and calcium-deficient diet rats $(-\mathrm{D}-\mathrm{Ca})$ had serum calciums of 5.1 $\mathrm{mg} / \mathrm{dl}$ with a 10 -fold increase in PTH mRNA. Therefore a calcium-deficient diet increased PTH mRNA much more than a vitamin D-deficient diet, and their combined deficiency was additive. Mean body weights of the rats were: $\mathrm{NDNCa}, 175 \mathrm{~g}$; $\mathrm{ND}+\mathrm{Ca}, 160 \mathrm{~g}$; -DNCa, $150 \mathrm{~g}$; ND-Ca, $140 \mathrm{~g}$; and -D-Ca, $100 \mathrm{~g}$. A Northern blot showed that the diets did not alter the mobility of the single 833-bp PTH mRNA band, and the intensity of the bands corresponded to the results derived from the dot blots (Fig. 2).

After 8 wk of the diets given to weanling rats PTH mRNA levels were increased in rats with the calcium-deficient diets (ND-Ca, -D-Ca) but not in rats with vitamin D-deficient diets $(-\mathrm{DNCa} ;-\mathrm{D}+\mathrm{Ca})$ (Table I). A high calcium diet $(\mathrm{ND}+\mathrm{Ca},-\mathrm{D}+\mathrm{Ca})$ for $8 \mathrm{wk}$ had no effect on PTH mRNA levels (Table I).

Further studies were performed on rats after $3 \mathrm{wk}$ on the diets. We had previously shown that when $1,25(\mathrm{OH})_{2} \mathrm{D}_{3}$ was injected intraperitoneally to normal rats (NDNCa) there was a marked reduction in PTH mRNA levels with as little as 12.5 pmol of $1,25(\mathrm{OH})_{2} \mathrm{D}_{3}$ (results from reference 8 reproduced in Fig. 3). In contrast, after a vitamin D-deficient diet rats (-D-Ca and $-\mathrm{DNCa}$ at $3 \mathrm{wk})$ showed no response to single doses of $1,25(\mathrm{OH})_{2} \mathrm{D}_{3}$ as high as $1 \mathrm{nmol}$ (Fig. 3). When the $-\mathrm{D}-\mathrm{Ca}$ and $-\mathrm{DNCa}$ were given repeated doses of $1,25(\mathrm{OH})_{2} \mathrm{D}_{3}(100 \mathrm{pmol})$ for 3 or $5 \mathrm{~d}$, there was a reduction in

Table I. The Effects of 8 wk of Diets Given to Weanling Rats

\begin{tabular}{lccc}
\hline & $\begin{array}{c}\text { Body weight } \\
(\text { mean })\end{array}$ & $\begin{array}{c}\text { Serum calcium } \\
(\text { mean } \pm S E[n])\end{array}$ & $\begin{array}{c}\text { PTH mRNA } \\
(\text { mean } \pm S E[n])\end{array}$ \\
\hline ND NCa & $g$ & $m g / d l$ & oD units \\
ND -Ca & 320 & $10.4 \pm 2(4)$ & $2.8 \pm 1.1(4)$ \\
ND +Ca & 150 & $6.6 \pm 0.6(4)^{*}$ & $6.6 \pm 0.6(4)^{*}$ \\
$-D ~ N C a$ & 300 & $11.2 \pm 1(4)$ & $1.9 \pm 1(4)$ \\
$-D-C a$ & 320 & $10.7 \pm 1(3)$ & $1.3 \pm 0.6(3)$ \\
$-D+C a$ & 110 & $4.4 \pm 0.6(3)^{\ddagger}$ & $7.6 \pm 1.3(3)^{\ddagger}$ \\
& 250 & $11.0 \pm 0.2(3)$ & $1.5 \pm 0.7(3)$
\end{tabular}

$n$, number of rats.

$P<0.05$ compared with ND NCa $\left(^{*}\right)$, or - D NCa $\left(^{\ddagger}\right)$. 


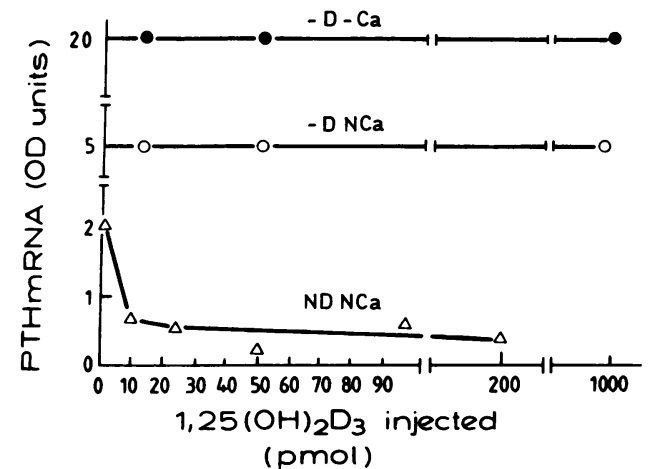

Figure 3. $1,25(\mathrm{OH})_{2} \mathrm{D}_{3}$ dose-response effect on parathyroid gland PTH mRNA $24 \mathrm{~h}$ after intraperitoneal injections, to rats on control diets (NDNCa) (from reference 8); vitamin D-deficient, normal calcium $(-D N C a)$ and calcium-deficient $(-D-C a)$. The results represent the mean for four rats.

PTH mRNA levels that was only significant in the -DNCa $(P$ $<0.05$ ) (Fig. 4).

In NDNCa rats, at $1 \mathrm{~h}$ after small reductions in serum calcium there were large increases in PTH mRNA levels (4), so we examined the response at $1 \mathrm{~h}$ to changes in serum calcium. ND-Ca rats increased their PTH mRNA levels when their serum calciums were reduced by administration of intraperitoneal calcitonin (Fig. 5). On the other hand, -D-Ca rats' PTH mRNAs were not altered when serum calcium was decreased to $3.0 \mathrm{mg} / \mathrm{dl}$ or increased to $12 \mathrm{mg} / \mathrm{dl}$ (Fig. 5). At a serum calcium of $2.0 \mathrm{mg} / \mathrm{dl}$ there was a large decrease in PTH mRNA in -D-Ca rats, and at a longer time interval $(3 \mathrm{~h})$ with an excessive serum calcium $(24 \mathrm{mg} / \mathrm{dl})$, there was a decrease (10 OD units) (data not shown). In our previous work, when NDNCa rats were injected with calcium, the serum calcium increased from 11 to $25 \mathrm{mg} / \mathrm{dl}$ at $1 \mathrm{~h}$ but there was no change in PTH mRNA levels (4).

\section{Flow cytometry studies}

Identification of cell populations. A mixed cell suspension from thyroparathyroid tissue when separated on the flow cytometer by size demonstrated at least two populations of cells. There was an initial peak of smaller cells (0-100 nm) and a later peak (101-254 nm) of larger cells (Fig. 6). The cells from the two peaks were separated by a cell sorter and then analyzed for mRNA content. The smaller cells contained only PTH mRNA and not thyroglobulin mRNA, whereas the second peak of larger cells hybridized with the thyroglobulin CDNA and not with the PTHc DNA (Fig. 6), demonstrating that the parathyroid and thyroid cells were clearly separated by the flow cytometer. This method was then used to determine the number of cells in each peak in control rats (NDNCa) and rats with the highest PTH mRNA levels $(-\mathrm{D}-\mathrm{Ca})$. To demonstrate that the cells were viable with intact membranes a suspension of cells derived from parathyroid-thyroid tissue was incubated with FDA for $1 \mathrm{~min}$ and then analyzed by fluorocytometry. Fluorocytometry of the cells with FDA demonstrated that $80 \%$ of the cells were in a large fluorescent peak indicating viable cells (10-12).

Cells from the two peaks from control rats (NDNCa) and -D-Ca rats were collected after separation by the cell sorter and studied for cell viability and cytological homogeneity. Flu- orescein diacetate (FDA) was not used on these diluted samples because the cell concentration was too low, and rather than introduce a further step of centrifugation, the cells were incubated with propidium iodide. Propidium iodide only penetrates cells where the cell membrane is not intact, binds to nuclear DNA, and fluoresces (10). Approximately $90 \%$ of the cells from both peaks from rats on NDNCa and -D-Ca diets were intact by this methodology.

Cytology of the cells from the peaks of NDNCa and $-\mathrm{D}-\mathrm{Ca}$ rats demonstrated that $(a)$ the first peaks had uniformly smaller cells than the second peaks, $(b)$ most of the cells were intact, $(c)$ there was very little contamination with other cell types (data not shown).

Determination of parathyroid cell number. Thyroparathyroid tissue from normal rats (NDNCa) and $-\mathrm{D}-\mathrm{Ca}$ rats was digested by collagenase and the suspension of single cells was passed through a flow cytometer. The percentage of cells in the first peak containing the parathyroid cells as compared with the second peak of larger thyroid cells was determined. There were $24.7 \pm 3.4 \%(n=6)$ parathyroid cells in the rats on the normal diet as compared with $41.8 \pm 6.6 \%(n=6)$ parathyroid cells in the rats on a vitamin $D$ - and calcium-deficient diet for 3 wk (-D-Ca). In other words there were 1.7 -fold more parathyroid cells in $-\mathrm{D}-\mathrm{Ca}$ rats than in NDNCa rats. This same ratio of 1.7:1 for-D-Ca:NDNCa parathyroid cells was found in two separate flow cytometry experiments.

\section{Discussion}

The molecular mechanisms involved in the pathogenesis of secondary hyperparathyroidism and the response to chronic hypercalcemia have been elusive because of methodological difficulties. However, the methodology reported here for measuring PTH gene expression and parathyroid cell number by flow cytometry has allowed an analysis of the separate contributions of changes in PTH gene transcription per cell and parathyroid cell number to secondary hyperparathyroidism. This methodology, as well as the recent development of electron microscopy stereologic methods for measuring parathyroid cell number and size by Wernerson et al. (13) will allow a

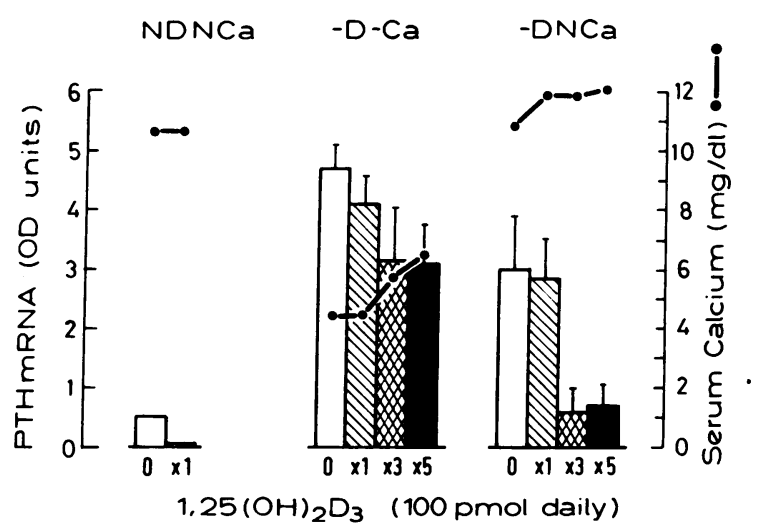

Figure 4. Effect of daily injections of $1,25(\mathrm{OH})_{2} \mathrm{D}_{3}(100 \mathrm{pmol})(0,1$, 3 , and $5 \mathrm{~d})$, to control rats (NDNCa); rats deficient in vitamin $\mathrm{D}$ and calcium $(-D-C a)$; and vitamin D-deficient, normal calcium $(-D N C a)$, on PTH mRNA. The mean \pm SEM for four rats is shown, as well as the mean serum calcium. 


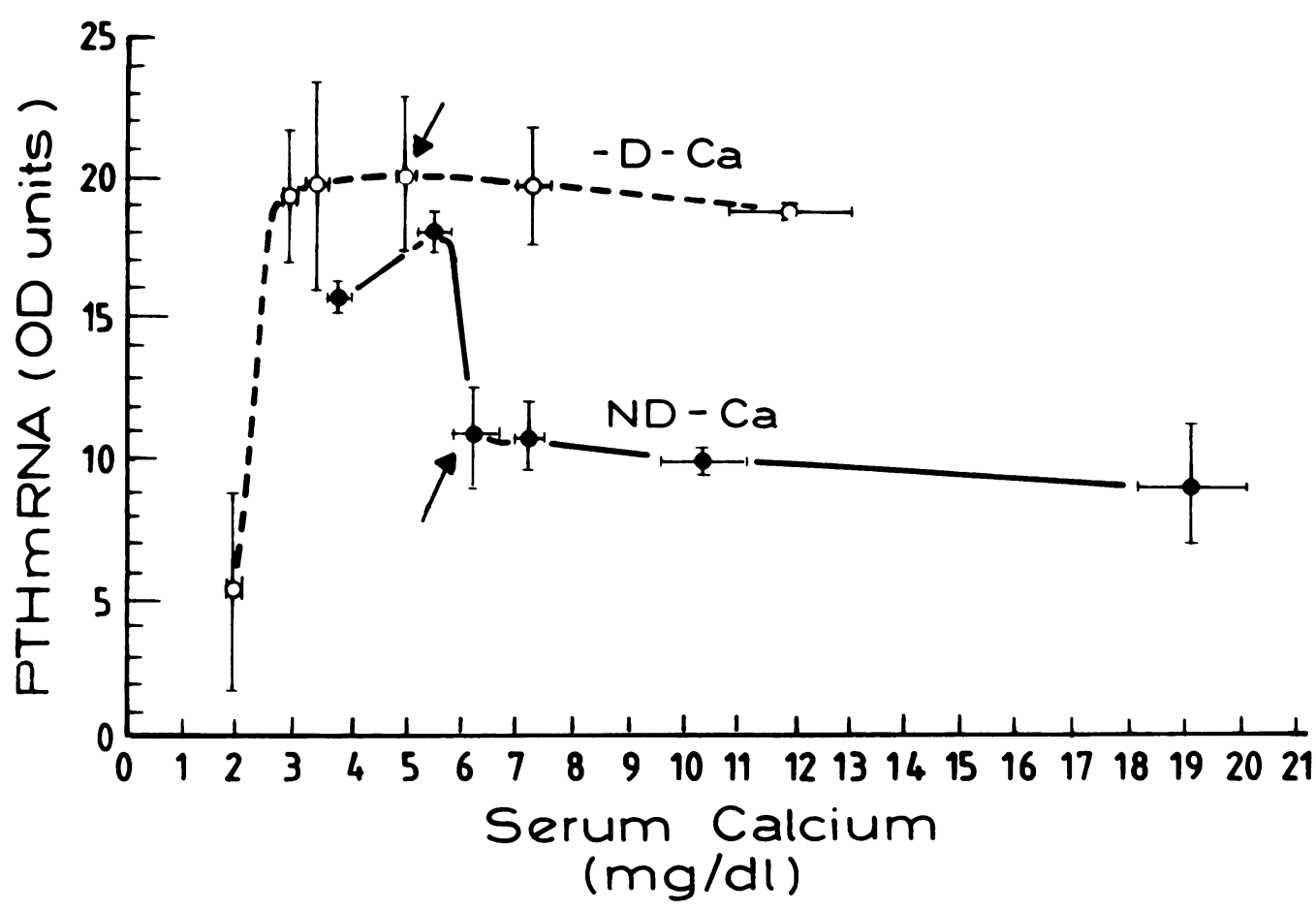

Figure 5. Effect of changes in serum calcium at $1 \mathrm{~h}$ on rat PTH mRNA for calcium-deficient rats on normal vitamin $\mathrm{D}(\mathrm{ND}-\mathrm{Ca})$ or vitamin D-deficient and calcium-deficient $(-D-C a)$ diets. The arrows indicate the serum PTH mRNA levels for the rats on the two diets before the changes in serum calcium. The mean \pm SEM of four rats is shown. clearer understanding of secondary hyperparathyroidism and its treatment.

In the present study, we used a dietary model of secondary hyperparathyroidism using diets deficient in calcium and/or vitamin $\mathrm{D}$, the main components of the secondary hyperparathyroidism of chronic renal failure. An increased PTH mRNA was the index of secondary hyperparathyroidism, and rats placed on diets for $3 \mathrm{wk}$ after weaning had as marked changes as those on the diets for $8 \mathrm{wk}$; therefore more detailed studies were performed on rats after $3 \mathrm{wk}$ of the diets. Moreover, studies on experimental uremia in the rats which showed marked effects on parathyroid cell proliferation were performed at $3 \mathrm{wk}$ (14). It is not clear why the PTH mRNA levels were increased in -DNCa rats at $3 \mathrm{wk}$, but not in rats on the same diet at $8 \mathrm{wk}$, an issue which warrants further study.

In the present study, the $-\mathrm{D}-\mathrm{Ca}$ rats were lighter at $3 \mathrm{wk}$, and had lower serum $1,25(\mathrm{OH})_{2} \mathrm{D}$ levels, whereas the -DNCa rats were not lighter and had normal serum calciums. The mechanism whereby the-DNCa rats had higher PTH mRNA levels despite normal serum $1,25(\mathrm{OH})_{2} \mathrm{D}$ is not clear but might possibly represent a lower total body vitamin $\mathrm{D}$ content, decrease in other vitamin $\mathrm{D}$ metabolites that might affect the $1,25(\mathrm{OH})_{2} \mathrm{D}_{3}$ receptor, or possibly changes in free $1,25(\mathrm{OH})_{2} \mathrm{D}$ levels rather than total $1,25(\mathrm{OH})_{2} \mathrm{D}$ levels which were measured in this study.

The -D-Ca group with the largest increase in PTH mRNA levels not only had low serum calciums but also were the only group to have low serum $1,25(\mathrm{OH})_{2} \mathrm{D}$ levels. Both of these factors could be responsible for the striking changes in PTH mRNA in this group. They also had the lowest body weights (mean of $100 \mathrm{~g}$, NDNCa $=175 \mathrm{~g}$ ) and since pair feeding was not performed, it is not possible to eliminate the possibility that starvation or malnutrition contributed to the results in this group.
The very high serum $1,25(\mathrm{OH})_{2} \mathrm{D}$ levels in rats on $\mathrm{ND}-\mathrm{Ca}$ is well known (15). What is of interest is that despite the high serum $1,25(\mathrm{OH})_{2} \mathrm{D}$ levels the PTH mRNA levels were fivefold those of ND NCa which indicates the dominant effect of low calcium whether it be on transcription or on replication or both. In acute studies, we had showed that the effect of $1,25(\mathrm{OH})_{2} \mathrm{D}$ in decreasing PTH mRNA levels was dominant over the effect of a low calcium in increasing PTH mRNA, but this seems not to be the case in long-term studies (4). Moreover, ND-Ca rats responded to acute hypocalcemia by increasing their PTH mRNA, suggesting an intact response (Fig. 5). However, they did not decrease their PTH mRNA after increasing the serum calcium to normal or very high levels at 1 h. Studies at longer times were not performed.

The results of these in vivo chronic studies supplement those of our earlier acute studies and together allow a clearer understanding of the regulation of PTH gene expression in vivo. A high calcium diet that led to a high serum calcium at 3 wk did not decrease PTH mRNA levels. This is in agreement with our short-term studies up to $6 \mathrm{~h}$ (4). Wernerson et al.'s (13) stereologic study of the parathyroids of rats with diet-induced hypercalcemia demonstrated that the parathyroid cell number and volume were the same as in weight-matched controls. Nussbaum et al. (16) produced a model of secondary hyperparathyroidism in rats by the implantation of fibroblasts that had been transfected with a human PTH gene, and preliminary results showed that these rats also had no decrease in their parathyroid gland PTH mRNA by in situ hybridization despite hypercalcemia. Also, in patients after removal of a parathyroid adenoma, the serum calcium rapidly normalizes, unless there is a "hungry bones" phenomenon, suggesting an intact PTH biosynthetic mechanism. These data all indicate that high calcium regulates PTH secretion and catabolism but not PTH gene transcription. 

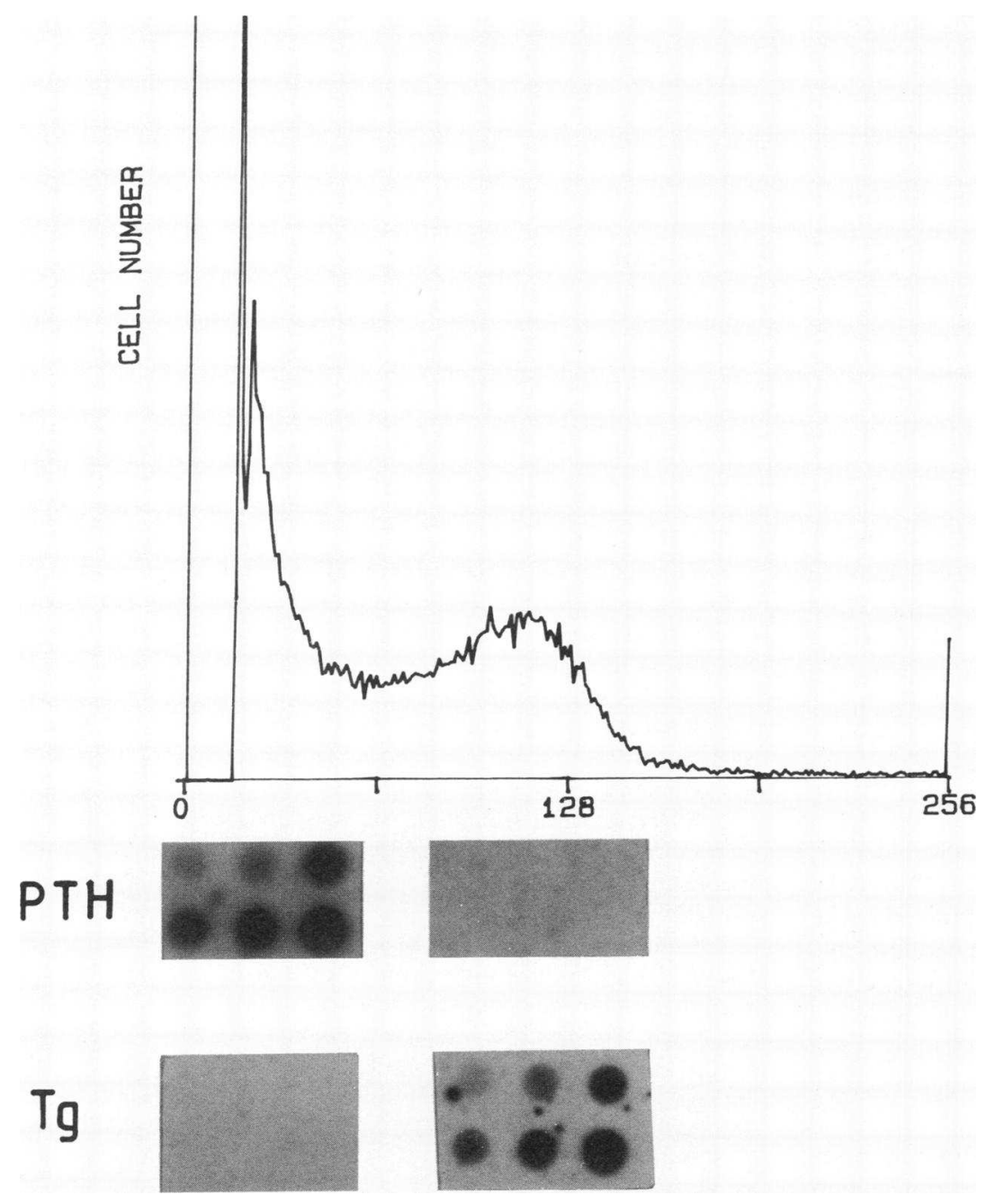

Figure 6. Flow cytometric analysis of dispersed cells from rat parathyroid-thyroid tissue. The cells from each peak were collected and hybridized sequentially with PTH cDNA and thyroglobulin cDNA $(T g)$.

3 wk of a vitamin D-deficient diet, regardless of the serum calcium, led to a twofold increase in PTH mRNA. Hendy et al. (17) found that vitamin D-deficient dogs also had a twofold increase in PTH mRNA levels. The moderately increased PTH mRNA of vitamin D deficiency might be a result of increased transcription per cell, because $1,25(\mathrm{OH})_{2} \mathrm{D}_{3}$ 's action on the PTH gene is to dramatically decrease transcription (8) as well as parathyroid cell hyperplasia, because both in vitro (13) and in chronic renal failure rats $(14) 1,25(\mathrm{OH})_{2} \mathrm{D}_{3}$ inhibited parathyroid cell proliferation. The effect of a low calcium in the present study was to dramatically increase PTH mRNA levels, in rats who had been fed both vitamin D-replete and -deplete diets. This is in agreement with our in vivo studies at 1-6 h, and Yamamoto's studies at $48 \mathrm{~h}$ (3). The increased PTH mRNA as a result of a low calcium may be a combination of increased transcription per cell, cell hypertrophy (19), and increased cell number. Hypocalcemia is certainly the major stimulator of increased PTH mRNA levels, rather than a vitamin D-deficient diet.

The ability of these rats after calcium and/or vitamin D deficient diets to respond to stimuli of $1,25(\mathrm{OH})_{2} \mathrm{D}_{3}$, and acute changes in serum calcium, was then studied. Normal rats responded to a single injection of $12.5-50$ pmol of $1,25(\mathrm{OH})_{2} \mathrm{D}_{3}$ with a $>90 \%$ reduction in PTH mRNA (8). Vitamin D-deficient rats did not respond to a dose of $1,25(\mathrm{OH})_{2} \mathrm{D}_{3}$ as high as 1 nmol. When rats raised on a vitamin D-deficient diet were given daily injections of $100 \mathrm{pmol} 1,25(\mathrm{OH})_{2} \mathrm{D}_{3}$ there were modest reductions of PTH mRNA after 3 and $5 \mathrm{~d}$ of injections. The inability of rats raised on a vitamin D-deficient diet to respond to $1,25(\mathrm{OH})_{2} \mathrm{D}_{3}$ theoretically might be a result of downregulation of the vitamin $\mathrm{D}$ receptor. In other systems, $1,25(\mathrm{OH})_{2} \mathrm{D}_{3}$ has been shown to lead to upregulation of its receptor (20), which might explain the slightly better response to repeated doses in our experiments. In Fig. 4, the rats with the greater response to repeated $1,25(\mathrm{OH})_{2} \mathrm{D}_{3}$ doses were the -D-Ca group, and their serum calciums increased from 4.4 to $6.4 \mathrm{mg} / \mathrm{dl}$, probably due to increased dietary calcium absorption.

A further question that was addressed was whether rats with probably the most hyperplastic glands $(-\mathrm{D}-\mathrm{Ca}$; ND-Ca) responded to changes in serum calcium at $1 \mathrm{~h}$, as normal rats (NDNCa) do. ND-Ca rats increased their PTH mRNA by $80 \%$ when their serum calciums were reduced by an injection of calcitonin (Fig. 5). In contrast $-\mathrm{D}-\mathrm{Ca}$ rats did not respond to changes in their serum calcium at $1 \mathrm{~h}$ from 3 to $12 \mathrm{mg} / \mathrm{dl}$. When the serum calcium was reduced to the unphysiologic level of $2 \mathrm{mg} / \mathrm{dl}$ there was a large reduction in PTH mRNA but still twice that of controls (Fig. 5). In vitro, at very low extracellular calcium PTH secretion is completely turned off (21). Therefore, some extracellular calcium is needed for the para- 
thyroid cell to function normally. These results suggest, at least, that vitamin D is necessary for parathyroid glands' PTH mRNA levels to respond to acute changes in serum calcium.

It was important to determine whether the increase in PTH mRNA after the different diets was due to increased transcription per cell or to an increase in the number of parathyroid cells. One possible methodology was the use of in situ hybridization, but the sensitivity of this method is limited. We therefore elected to determine the number of parathyroid cells by producing a cell suspension from the thyro-parathyroid tissue, and then analyzing and characterizing the cells using a flow cytometer. Fortunately, there was a clear separation by size of the larger thyroid cells from the smaller parathyroid cells. The first peak, containing the parathyroid cells, would also contain cell debris but we demonstrated by the use of fluorescein diacetate (FDA) that we were dealing with viable cells. FDA is uncharged and lipid soluble and readily crosses cell membranes $(11,12)$. Once inside the cell, ester molecules are readily and rapidly hydrolyzed to free fluorescein by nonspecific esterases, which are present in almost all cells. The ester is not fluorescent, whereas the free fluorescein anion, which is retained by intact cells, renders them highly fluorescent (12). By this criterion $80 \%$ of the cells were viable with membrane integrity.

Comparison of NDNCa rats to $-\mathrm{D}-\mathrm{Ca}$ rats showed that -D-Ca rats had 1.7-fold the number of parathyroid cells compared with NDNCa rats. The PTH mRNA in the $-\mathrm{D}-\mathrm{Ca}$ rats was 10 -fold higher than the NDNCa rats. Therefore the increased PTH gene expression per parathyroid cell accounted for most of the increase in PTH mRNA (6-fold), whilst increased cell number accounted for much less (1.7-fold). This methodology lends itself to further studies on the regulation of parathyroid cell replication.

These in vivo studies therefore indicate that after long-term dietary changes PTH mRNA levels were not affected by a high calcium, were increased by a vitamin D-deficient diet and even more so by calcium deficiency. Rats that had been on a vitamin D-deficient diet for $3 \mathrm{wk}$ did not respond normally to acute stimuli of $1,25(\mathrm{OH})_{2} \mathrm{D}_{3}$ or changes in serum calcium. The results of these studies are relevant to our understanding of the pathophysiology of parathyroid hyperplasia in human vitamin $\mathrm{D}$ deficiency and chronic renal failure.

In chronic renal failure patients, severe secondary hyperparathyroidism develops as a consequence of low $1,25(\mathrm{OH})_{2} \mathrm{D}_{3}$ levels $(22)$ and a low serum calcium. Early treatment with $1,25(\mathrm{OH})_{2} \mathrm{D}_{3}$ and calcium prevents the hyperparathyroidism and the bone disease (23-25), however established secondary hyperparathyroidism is very resistant to therapy. In both human and experimental chronic renal failure a decreased number of parathyroid $1,25(\mathrm{OH})_{2} \mathrm{D}_{3}$ receptors has been demonstrated (26-28), and immunoreactive PTH levels have been shown to decrease after large, repeated doses of $1,25(\mathrm{OH})_{2} \mathrm{D}_{3}$, and only minimally to increases in serum calcium (29). Those findings are similar to the results of the present study using a dietary model of secondary hyperparathyroidism where PTH mRNA levels decreased after repeated $1,25(\mathrm{OH})_{2} \mathrm{D}_{3}$ doses but not to increases in serum calcium.

\section{Acknowledgments}

Dr. H. Mayer for providing the PTH clone (Hoffman-La Roche Inc.), Basle for the $1,25(\mathrm{OH})_{2} \mathrm{D}_{3}$, Dr. S. Edelstein of the Weizmann Institute
(Rehovot, Israel) for performing the serum $1,25(\mathrm{OH})_{2} \mathrm{D}$ assays, and Ms. M. Ofner for technical assistance.

This work was supported by grants from the National Institutes of Health (DK 38696), the US-Israel Binational Science Foundation (BSF), and the German-Israel Foundation for Science and Development (GIF).

\section{References}

1. Russell, J., D. Lettieri, and L. M. Sherwood. 1983. Direct regulation by calcium of cytoplasmic messenger ribonucleic acid coding for pre-proparathyroid hormone in isolated bovine parathyroid cells. $J$. Clin. Invest. 72:1851-1855.

2. Brookman, J. J., S. M. Farrow, L. Nicholson, J. L. H. O'Riordan, and G. N. Hendy. 1986. Regulation by calcium of parathyroid hormone mRNA in cultured parathyroid tissue. J. Bone Miner. Res. 1:529-537.

3. Yamamoto, M., T. Igarashi, M. Muramatsu, M. Fukagawa, T. Motokura, and E. Ogata. 1989. Hypocalcemia increased and hypercalcemia decreases the steady-state level of parathyroid hormone messenger RNA in the rat. J. Clin. Invest. 83:1053-1058.

4. Naveh-Many, T., M. M. Friedlaender, H. Mayer, and J. Silver. 1989. Regulation by calcium of parathyroid hormone mRNA, but not calcitonin mRNA in vivo in the rat. Dominant role of 1,25-dihydroxyvitamin D. Endocrinology. 125:275-280.

5. Silver, J., J. Russell, and L. M. Sherwood. 1985. Regulation by vitamin D metabolites of messenger ribonucleic acid for preproparathyroid hormone in isolated bovine parathyroid cells. Proc. Natl. Acad. Sci. USA. 82:4270-4273.

6. Cote, G. J., D. G. Rogers, E. S. C. Huang, and R. F. Gagel. 1987. The effect of 1,25-dihydroxyvitamin $D_{3}$ treatment on calcitonin and calcitonin gene-related peptide mRNA levels in cultured human thyroid c-cells. Biochem. Biophys. Res. Commun. 149:239-243.

7. Okazaki, T., T. Igarashi, and H. M. Kronenberg. 1988. 5'-flanking region of the parathyroid hormone gene mediates negative regulation by 1,25-(OH $)_{2}$ vitamin $D_{3}$. J. Biol. Chem. 263:2203-2208.

8. Silver, J., T. Naveh-Many, H. Mayer, H. J. Schmelzer, and M. M. Popovtzer. 1986. Regulation by vitamin D metabolites of parathyroid hormone gene transcription in vivo in the rat. J. Clin. Invest. 78:1296-1301.

9. Naveh-Many, T., and J. Silver. 1988. Regulation of calcitonin gene transcription by vitamin D metabolites in vivo in the rat. J. Clin. Invest. 81:270-273.

10. Shapiro, H. M. 1941. Practical Flow Cytometry. Allan R. Liss, Inc., New York. 295 pp.

11. Resnick, M., S. Schuldiner, and H. Bercovier. 1985. Bacterial membrane potential analyzed by spectrofluorocytometry. Curr. Microbiol. 12:183-186.

12. Brunius, G. 1980. Technical aspects of the use of $3^{\prime}, 6^{\prime}$-diacetyl fluorescein for vital fluorescent staining of bacteria. Curr. Microbiol. 4:321-323.

13. Wernerson, A., O. Svensson, and F. P. Reinholt. 1989. Parathyroid cell number and size in hypercalcemic rats: a stereologic study employing modern unbiased estimators. J. Bone Miner. Res. 4:705713.

14. Szabo, A., J. Merke, E. Beier, G. Mall, and E. Ritz. 1989. $1,25(\mathrm{OH})_{2}$ vitamin $D_{3}$ inhibits parathyroid cell proliferation in experimental uremia. Kidney Int. 35:1049-1056.

15. Matsumoto, T., K. Ideka, H. Yamato, K. Morita, I. Ezawa, M. Fukushima, Y. Nishii, and E. Ogata. 1988. Effect of 24,25-dihydroxyvitamin $D_{3}$ on 1,25 -dihydroxyvitamin $D_{3}$ metabolism in calcium-deficient rats. Biochem. J. 250:671-677.

16. Nussbaum, S., J. Wilson, A. Thompson, C. Lupassakis, A. Rosenberg, R. Mulligan, J. T. Potts, Jr., and H. Kronenberg. 1989. Long-term expression of human PTH in rats after gene transfer into syngeneic fibroblasts: a model for osteoclast mediated bone resorption. J. Bone Miner. Res. 4:S323. 
17. Hendy, G. N., M. A. Stotland, D. Grunbaum, L. J. Fraher, N. Loveridge, and D. Goltzman. 1989. Characteristics of secondary hyperparathyroidism in vitamin D-deficient dogs. Am. J. Physiol. 256:E765-E772.

18. Nygren, P., R. Larsson, H. Johansson, S. Ljunghall, J. Rastad, and G. Åkerström. 1988. 1,25(OH $)_{2} D_{3}$ inhibits hormone secretion and proliferation but not functional dedifferentiation of cultured bovine parathyroid cells. Calcif. Tissue Int. 43:213-218.

19. Svensson, O., A. Wernerson, and F. P. Reinholt. 1988. Effect of calcium depletion on the rat parathyroids. Bone Miner. 3:259-269.

20. McDonnel, D. P., D. J. Mangelsdorf, J. W. Pike, M. R. Haussler, and B. W. O'Malley. 1987. Molecular cloning of complementary DNA encoding the avian receptor for vitamin D. Science (Wash. DC). 235:1214-1217.

21. Ramp, W. K., C. W. Cooper, A. J. Ross III, and S. A. Wells, Jr. 1979. Effects of calcium and cyclic nucleotides on rat calcitonin and parathyroid hormone secretion. Mol. Cell. Endocrinol. 14:205-215.

22. Lopez-Hilker, S., T. Galceran, Y.-L. Chan, N. Rapp, K. J. Martin, and E. Slatopolsky. 1986. Hypocalcemia may not be essential for the development of secondary hyperparathyroidism in chronic renal failure. J. Clin. Invest. 78:1097-1102.

23. Pitts, T. O., B. H. Piraino, R. Mitro, T. C. Chen, G. V. Segre, A. Greenberg, and J. B. Puschett. 1988. Hyperparathyroidism and 1,25- dihydroxyvitamin $\mathrm{D}$ deficiency in mild, moderate, and severe renal failure. J. Clin. Endocrinol. \& Metab. 67:876-881.

24. Nordal, K. P., and E. Dahl. 1988. Low dose calcitriol versus placebo in patients with predialysis chronic renal failure. J. Clin. Endocrinol. \& Metab. 67:929-936.

25. Baker, L. R. I., S. M. L. Abrams, C. J. Roe, M.-C. Faugere, P. Fanti, Y. Subayti, and H. H. Malluche. 1989. $1,25(\mathrm{OH})_{2} \mathrm{D}_{3}$ administration in moderate renal failure: a prospective double-blind trial. Kidney Int. 35:661-669.

26. Korkor, A. B. 1987. Reduced binding of $\left[{ }^{3} \mathrm{H}\right] 1,25-$ dihydroxyvitamin $\mathrm{D}_{3}$ in the parathyroid glands of patients with renal failure. N. Engl. J. Med. 316:1573-1577.

27. Merke, J., U. Hugel, A. Zlotkowski, A. Szabo, J. Bommer, G. Mall, and E. Ritz. 1987. Diminished parathyroid $1,25(\mathrm{OH})_{2} \mathrm{D}_{3}$ receptors in experimental uremia. Kidney Int. 32:350-353.

28. Brown, A. J., A. Dusso, S. Lopez-Hilker, J. Lewis-Finch, P. Grooms, and E. Slatopolsky. 1989. 1,25-(OH $)_{2} \mathrm{D}$ receptors are decreased in parathyroid glands from chronically uremic dogs. Kidney Int. 35:19-23.

29. Slatopolsky, E., C. Weerts, J. Thielan, R. Horst, H. Harter, and K. J. Martin. 1984. Marked suppression of secondary hyperparathyroidism by intravenous administration of 1,25-dihydroxycholecalciferol in uremic patients. J. Clin. Invest. 74:2136-2143. 